\title{
Advocating integrated water resources management approach for rural human settlements
}

\section{Opinion}

Water supply and sanitation are comparatively neglected areas in the rural areas of the developing countries. Historically, in India, the rural human settlements (villages) were self sufficient in fulfilling their water needs and managing the wastewater generated by storing and natural treatment in village ponds. But, increasing population and developmental pressures are leading to either encroachment or extinction of the village ponds. Increasing population and enhanced impervious areas are resulting in the increased flow of wastewater and stormwater to the village ponds, thus rendering them unfit for any beneficial use. Instead of being the source of water, village ponds are now posing serious environmental and health risks. Consequently, water requirements of the villages are now dependent on government sponsored water supply schemes and submersible pumps which result in exploitative use of the rapidly depleting and scarce ground water resources. Renovation of ponds has proved to be having positive effects on the environment, the rural economy and the groundwater regime. ${ }^{1,2}$ Instead of adopting a fragmented approach for tackling the water supply and sanitation problems in rural areas, it is imperative to adopt the integrated water resources management (IWRM) based integrated approach that should integrate water supply and sanitation sector in the rural human settlements. Principles of IWRM have mostly been applied to the larger catchments such as river basins and urban watersheds. Very few applications of IWRM have been reported in the predominantly rural settings. Application of IWRM is important in water supply and sanitation (WATSAN) sector, especially, where water is scarce or increasing competition among various water users (.i.e. WATSAN, agriculture, industry etc.) creates a situation of conflict among water users. IWRM offers an integrated approach for managing the multiple uses of water without creating a situation of conflict. ${ }^{3}$ Goal of any integrated water management should be the public health, sustainability and environmental protection. Municipal wastewater can be an important water resource for irrigation but its use must be regulated to prevent contamination of groundwater and undesirable health effects. ${ }^{4}$

Large scale abstractions and low recharge of aquifers necessitate the application of IWRM to the groundwater resources which will promote the groundwater resource sustainability. ${ }^{5}$ A more realistic approach for the implementation of IWRM is to focus on the local levels instead of basin or national level. This approach is termed as 'light' approach for IWRM application which takes into account the local realities and accepts that partial integration may sometimes fulfill the objectives of IWRM plan. To make the villages self dependent in water needs, local water planning should be given due importance in the rural areas. ${ }^{6}$ A successful water resources management is dependent on the expertise and knowledge of the local communities who are the key stakeholders in water conservation. Continuous interaction between IWRM planners and local people should take place for the success of water management programs. ${ }^{8}$ To find a solution to the water related problems which directly affect the communities, implementation of the theoretically agreed upon procedures of IWRM is required to ensure sustainable water resources

\author{
Volume 2 Issue 3 - 2018
}

\author{
Puneet Pal Singh Cheema, Preetinder Kaur \\ Department of Civil Engineering, Guru Nanak Dev Engineering \\ College, India
}

Correspondence: Puneet Pal Singh Cheema, Department of Civil Engineering, Guru Nanak Dev Engineering College, India, Email ppsc390@gmail.com

Received: December 10, 2017 | Published: May 03, 2018

management at the local level. ${ }^{9}$ By reviewing the literature it can be recommended that IWRM at the rural human settlements level should be able to address the following issues:

Protection and development of groundwater sources for ensuring secured supply of sufficient water of adequate quality (in the face of conflict, scarcity, pollution of the water resource) without compromising on the water supply to the competing agricultural and ecological use

Minimizing the impacts of groundwater abstraction and of pollution from the wastewater and stormwater on the groundwater and surface waters, on the health, environment and land resources, and on the agriculture and animal husbandry activities

Putting in place the processes that lead to sustainable solutions to the water supply and sanitation problems that resolve the local water conflicts (specially related to water access), minimize the infrastructure requirements and reduce costs.

\section{Acknowledgments}

None

\section{Conflict of interest}

The authors declare there is no conflict of interest.

\section{References}

1. Shivashankara G, Puneeta H. Quality status of water in village ponds for irrigation. National Environment and Pollution Technology. 2004;3:243-247.

2. Toor AS, Khurana MPS, Sidhu BS, et al. Suitability of village pond waters for irrigation: a case study from district Ludhiana, India. Environmental Monitoring and Assessment. 2011;172(1-4):571-579.

3. Moriarty P, Butterworth J, Batchelor C. Integrated Water Resources Management and the domestic water and sanitation sub-sector. IRC Thematic Overview Paper, IRC International Water and Sanitation Centre. 2004; 1-42.

4. Bouwer H. Integrated water management: Emerging issues and challenges. Agricultural Water Management. 2000;45(3):217-228.

5. Foster S, Ait-Kadi M. Integrated Water Resources Management(IWRM): how does groundwater fit in?. Hydrogeology Journal. 2012;20:415-418. 
6. Butterworth J, Warner J, Moriarty P, et al. Local approaches to Integrated Water Resources Management. Water Alternatives. 2010;3:68.

7. Dungumaro EW, Madulu NF. Public participation in integrated water resources management: the case of Tanzania. Physics and Chemistry of the Earth, Parts A/B/C. 2003;28(20-27):1009-1014.
8. National Water Mission. Guidelines for Integrated Water Resources Development and Management. National Water Mission, Government of India. 2010;33.

9. Biswas AK. Integrated water resources management: is it working?. International Journal of Water Resources Development. 2008;24(1):522. 